\title{
THE MACROECONOMIC DETERMINANTS AND THE IMPACT OF SANCTIONS ON FDI IN IRAN
}

\author{
Mehdi RASOULI GHAHROUDI', Li Choy CHONG²
}

\author{
${ }^{1}$ Institute for Management and Planning Studies (IMPS), Tehran, Iran \\ ${ }^{2}$ University of St. Gallen, St. Gallen, Switzerland
}

Corresponding author e-mail:_m.rasouli@imps.ac.ir

\begin{abstract}
We examine the impact of the macroeconomic determinants of foreign direct investment inflows. We also investigate the moderating role of sanctions in FDI inflows into Iran. The results reveal that macro determinants such as infrastructure, exchange rate, inflation rate, investment return, and governance have a long-run effect on FDI inflows in Iran. Our findings also show that GDP growth rate and trade openness have no significant effect on FDI. Our results indicate that sanctions do not have a significant moderating role in the relationship between macroeconomic factors and FDI. Surprisingly, international sanctions have a positive relationship with FDI inflows in Iran. Furthermore, sanctions have a positive impact on the inflation rate and exchange rate in Iran. Finally, our findings show that sanctions have had a significant impact on Iran's economic growth in recent years due to increasing the severity level of sanctions.
\end{abstract}

Keywords: FDI inflows, GDP growth, Iran, macroeconomic factors, sanctions, political stability.

JEL Classification: F21, F62, F4

\section{INTRODUCTION}

Foreign direct investment is an indispensable source of finance for developing countries, but policymakers must minimise their risks. FDI can help host countries generate employment, technology diffusion, economic growth and sustainable development (UNCTAD, 2015). The World Bank's edition of global development finance emphasises the importance of 'absorptive capacities' in the success of FDI. However, according to Alfaro et al. (2004), absorptive capacities include (1) macroeconomic management (e.g., inflation and trade openness), (2) infrastructure (e.g., telephone lines and paved roads), and (3) human capital (e.g., share of the labour force with secondary education and percentage of the population with access to sanitation). Furthermore, a potential risk in developing countries should be minimised through good governance and strong institutions, high absorption capacity and an effective legal framework (UNCTAD, 2015). However, prospects for global FDI inflows are good, with a projected growth of 11 percent to $\$ 1.37$ trillion in 2015. It is expected that global FDI flows may increase further to $\$ 1.5$ trillion in 2016 and \$1.7 trillion in 2017. Thus, UNCAD's FDI forecast model and 
its survey related to multinational enterprises (MNEs) show an increasing rise in FDI flows in the future.

According to UNCTAD (2017), weak oil prices and political uncertainty continue to affect FDI inflows in West Asia, including Iran. FDI flows to the region in 2016 dropped by 2 percent to $\$ 28$ billion due to persistently low oil prices, political and geopolitical uncertainties, as well as regional conflicts. FDI figures for oil and gas do not give a detailed picture of FDI in the industry; however, foreign entry into oil and gas industries often includes unconventional arrangements such as management contracts and production sharing agreements. Depending on the levels of economic, social, and political development, there is much literature on determinants of the FDI inflows (for example, Stack et al., 2017; Villaverde \& Maza, 2015; Naude \& Asiedu, 2002). There are studies on market size and growth (Bevan \& Estrin, 2004); availability of natural resources (e.g., Elheddad, 2017); skilled and qualified human capital (e.g., Kar 2013; Ndeffo, 2010); quality of infrastructure (Cheng \& Kwan, 1999) and government policies (Cleeve, 2008); governance quality (Abdioglu et al., 2013) and political stability (Cleeve, 2012; Musibah, 2015). Therefore, these factors might help countries with slow or high economic growth. In other words, countries that have FDI determinant factors are more likely to attract foreign direct investment. However, in the absence of FDI determinants, some countries might lose out on the attraction and retention of FDI (Cleeve et al., 2015).

While it is generally assuming that the boycott of bilateral direct trade between the United States and Iran has been the channel for economic losses for both sides, nothing could be further from the truth. For Iran, the real cost of direct trade losses is partly due to the impact of the decline in FDI, capital inflows and joint ventures. The impact of these non-trade effects on Iran is significant and, as a result, it will be difficult for Iran to go back to business as usual with the US and its allies when sanctions are lifted (Askari et al., 2002). Our research has two contributions. First, we identify and empirically examine the issue of sanctions on FDI, which is less considered in the literature, and, second, we attempt to shed light on the FDI determinants by examining macroeconomic factors and the business environment in light of Iran's policymaking on its FDIs. By the same token, this study would attempt to investigate the impact of macroeconomic factors and the imposed sanctions on Iran's capability of attracting FDI inflows.

\section{FDI INFLOW IN IRAN}

Iran is considered an energy superpower. According to Goldman Sachs (2011), Iran has the potential to become one of the world's largest economies in the $21 \mathrm{st}$ century. Iran as OPEC's second-largest oil producer possess approximately 94 billion barrels (10 percent of world oil reserves); and has 812 trillion cubic feet reserves of natural gas in the world (17 percent of total). Iran also has enormous mineral resources, including iron, coal, copper, sulphur, zinc, as well as gold. Thus, these natural resources generate several processing industries. However, in the case of doing business with Iran, political and currency stability are considered the most 
problematic factors. Furthermore, due to sanctions, adversity to access international financing is also a major concern.

According to recent policy in Iran, the development of non-oil exports is a priority. Iran has a broad domestic industrial base, an educated and motivated workforce, energy resources and geographical location advantages, which provide access to an estimated population of 300 million people in Caspian markets, Persian Gulf states, and countries further east.

The years of government control over the economy and the lack of private investment coupled with market liberalization and recent reforms have led to interesting business and investment opportunities in many sectors. However, there is no challenge in finding areas of the Iranian economy that require investment.

Despite the uncertainty about the nuclear energy policy, the level of technology and infrastructure available to many industries in Iran makes it possible to develop partnerships with foreign companies. In fact, the presence of MNCs in Iran has increased dramatically over the past 20 years, due to open regulatory policy that makes multinational corporations face less difficulty in investing in Iran (Soltani \& Wilkinson, 2011). According to the Vision 2025 plan of the Iranian government, within two decades (2005-2025), Iran needs \$ 3.7 trillion investment, of which $\$ 1.3$ trillion should be in form of foreign investment. Table 1 shown FDI inflows and outflows in the last six years.

Table 1. Iran FDI flows 2011-2018 (Millions of USD)

\begin{tabular}{|c|c|c|c|c|c|c|c|c|c|c|c|c|}
\hline \multirow[b]{2}{*}{ Year } & \multicolumn{6}{|c|}{ FDI Inflows } & \multicolumn{6}{|c|}{ FDI Outflows } \\
\hline & 2013 & 2014 & 2015 & 2016 & 2017 & 2018 & 2013 & 2014 & 2015 & 2016 & 2017 & 2018 \\
\hline Iran & 3050 & 2105 & 2050 & 3372 & 5019 & 3480 & 146 & 605 & 120 & 104 & 76 & 75 \\
\hline
\end{tabular}

The opening of the Iranian market for foreign investment can also create a new investment opportunity for multinational corporations that invest in different sectors of production and services in the next decade of about $\$ 600$ billion to $\$ 800$ billion in Iran. Foreign investors focus on several sectors of Iran's economy, including oil and gas industries, vehicle manufacturing, copper extraction, petrochemicals, food, and pharmaceuticals. Iran absorbed US $\$ 34.6$ billion in financing for 485 projects from 1992 to 2009, and \$24.3 billion of foreign investment from 1993 to 2007. Fig. 1 demonstrates the trend of FDI inflows in Iran from 1990 to 2018 according to UNCTAD (2019) reports.

Jafarnejad et al. (2009) found a significant positive impact of openness of trade and GDP per capita have on FDI. Further, inflation, oil extraction, and production had a negative correlation with FDI. Furthermore, infrastructural factors, market size, research and development (R\&D), education and scientific output encourage FDI inflows. Soltani and Wilkinson's study (2010) examines international assignees' perceptions and experiences in a sample of Iranian-based MNC affiliates in high growth sectors. Their study indicates that the international assignees' perceptions of managing an MNE affiliate in Iran were often formed before their departure and their performance was strongly linked to the level of congruence 
between MNC and subsidiary's managerial orientation. Their finding reveals that performance tends to deteriorate when subsidiaries are requested to conform to MNC policies and practices.

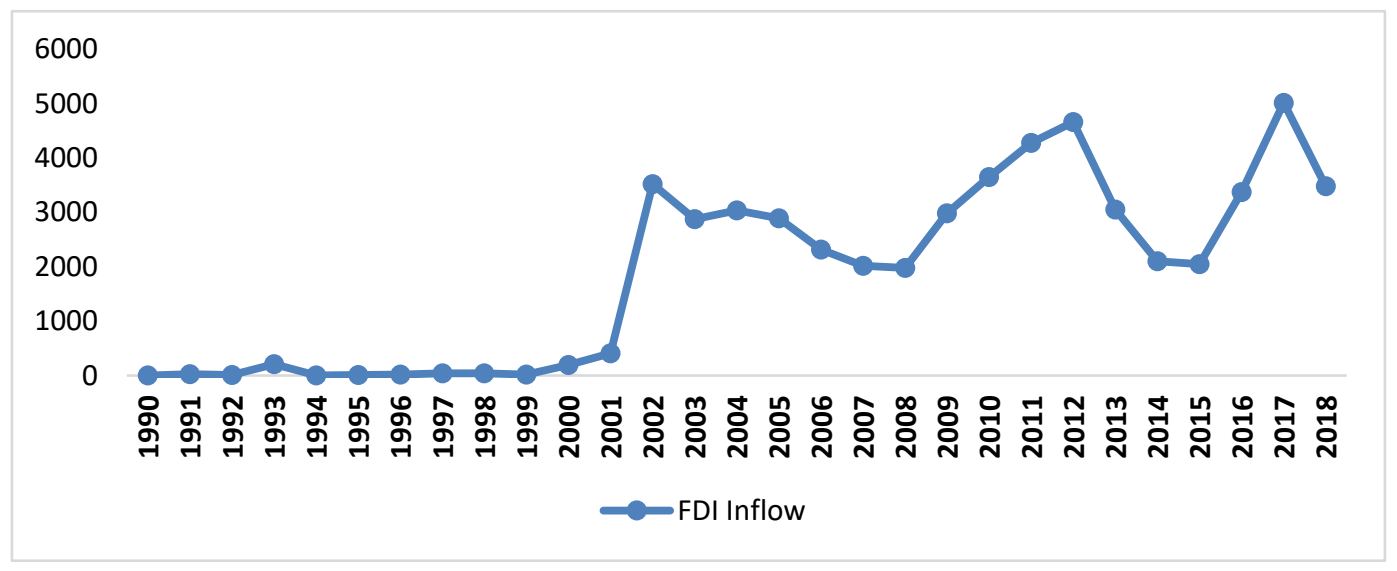

Fig. 1. Iran's FDI inflow during the period of 1990-2018.

\subsection{Gross Domestic Product}

The GDP growth rate is a measure of the country's economic performance. The national economic development can be determined by criteria such as the amount of production, consumption, quality, diversity of goods, and other economic indicators (Musibah et al., 2015). The growth of GDP can be a determinant of FDI inflows to countries (UNCTAD, 1998). However, Sahoo (2006) asserts that countries with a higher and sustained growth rate will receive more FDI flows. Kahai (2011) argues that foreign investors consider the size of the current market as well as the potential for future growth in the market. Moreover, many studies have mentioned the importance of GDP growth (Stack, 2017; Arbatli, 2011; Nonnemberg \& Mendonca, 2004).

Mina (2014) studied 52 middle-income countries and found an effect of GDP on FDI. Further, Pradhan and Kelkar (2014) and Badr \& Ayed's (2015) studies indicated a positive relationship between GDP and FDI inflow. Furthermore, favourable investment conditions and the rapid economic development in a host country would attract FDI.

H1. GDP growth has a positive impact on FDI inflows.

\subsection{Infrastructure}

Good infrastructure is essential in recipient countries to realise FDI benefits. The existence of developed infrastructure significantly reduces the transaction cost of investment and, as a result, increases investment returns (Morisset, 2001). Therefore, a good infrastructure is one of the characteristics of economic development. The literature on development economics also emphasises the need for access to basic infrastructure for poverty alleviation (Yamin and Sinkovics, 2009). 
Iran has a strong and extensive economic infrastructure. For an instant, Iran's transportation network includes 12000 kilometres of railways and 220000 kilometres of roads. The country has nine commercial facilities in the south, including the Shahid Rajaee port in the north of the Strait of Hormuz, which deals with more than 80 foreign ports through 35 container lines. Moreover, there are three commercial ports of the Caspian Sea in the north. Iran now has 167 Internet servers or 2.12 per million people and 31 percent of the people use the Internet. Furthermore, Iran has 29 million landline numbers and 65 million mobile phone numbers.

H2. Infrastructure has a positive impact on FDI inflows.

\subsection{Exchange Rate}

The literature acknowledges that there is a relationship between the exchange rate and the inflow of foreign direct investment. For instance, Clare \& Gang (2010), Kiyota \& Urata (2008) and Mowatt \& Zulu (1999) have learned that the exchange rate could lead to fluctuations in foreign direct investment by affecting the cost of acquiring foreign currency. This is because the devaluation of the domestic currency against the value of the foreign currency will make the investment less expensive for a foreign investor in the host country. However, depreciation of the domestic exchange rate will stimulate foreign direct investment inflows to that country (Musibah et al., 2015). On the other hand, if the value of a country's currency is decreasing, foreign investors are encouraged to buy assets at lower prices in that country (Blonigen \& Ma, 2011).

H3. The exchange rate has an impact on FDI inflows.

\subsection{Inflation Rate}

The rate of inflation represents the overall financial performance of host countries. Further, high inflation indicates the government's failure to manage the country's budget (Hailu, 2010; Schneider \& Frey, 1985). Inflation is considered an important element in the flow of foreign direct investment. In general, higher inflation rates will reduce FDI inflows (Bissoon, 2012; Kok \& Ersoy, 2009). However, inflation has a positive impact on FDI (Ali, Khrawish, \& Siam, 2010; Azam \& Lukman, 2010). In contrast, studies such as Shahzad and Al-Swidi (2013), Anyanwu (2012) and Parajuli \& Kennedy (2010) have found no significant relationship between inflation and FDI inflow.

H4. The inflation rate has an impact on FDI inflows.

\subsection{Political Stability}

Alcantara and Mitsuhashi (2013) reveal that political risk is one of the risks that affects the choice of the location and indicates the unpredictability and instability of legal and political conditions in a host country. Host countries where the political structure or even the preferences of policymakers are unstable create more uncertainty and risk for MNCs, because changes in laws, taxes, and government permission after entry have led to undesirable shifts of their FDI (Henisz and Macher, 2004; Globerman and Shapiro, 2003; Delios and Henisz, 2003). 
Shahzad et al. (2012) and Younis et al. (2008) reveal that political instability has a significant impact on FDI inflow. Madani and Nobakht, (2014) and Kim, (2010) assert that property rights and civil rights as proxies of political stability have a key role in the attraction of FDI into the country.

H5. Political stability has a positive impact on FDI inflows.

\subsection{Trade Openness}

The traditional neoclassical theory states that the liberalization of trade and investment accelerate technological progress, improves labour efficiency, increases trade, and ultimately boosts economic growth (Cleeve et al., 2015). The positive association between trade openness and FDI has led to many studies in developing countries, for example, Little et al. (1970) studied the association of trade orientation and economic performance in developing countries. The more a country opens up its domestic market to external trade, the more the country can attract FDI. Trade openness is captured by the ratio of the country`s exports plus imports to the GDP (Sahni, 2012; Nunes et al., 2006). In the host country, two main channels determine the relationship between trade and FDI. First, countries with a high degree of openness tend to attract more FDI inflows. Second, the inflow of foreign direct investment can affect trade flows through technology transfer and export expansion in the manufacturing sector (Chowdhury \& Mavrotas, 2006).

In the case of Iran, the total volume of imports increased by 189 percent from $\$ 13.7$ billion in 2000 to $\$ 39.7$ billion in 2005 and $\$ 55.189$ billion in 2009 . Over the past five years, Iran's imports have fallen by 8.9 percent year-on-year, from $\$ 70.4$ billion in 2010 to $\$ 43.9$ billion in 2015, and Iran is currently the world's 51 largest importer. The main trading partners of Iran are China, India, Germany, Japan, France, South Korea, Italy, and Russia. About 80 percent of machines and equipment in Iran are of German origin (Gheissari, 2009). Trade openness is considered a key determinant of FDI and it is generally expected to have a positive influence on FDI inflows (Sahni, 2012; Sahoo, 2006; Asiedu, 2002).

H6. Trade openness has a positive impact on FDI inflows.

\subsection{Investment Return}

Foreign direct investment goes to countries with higher returns. However, finding a suitable measure for the return on investment for developing countries is difficult due to the lack of a well-functioning capital market (Asiedu, 2002). Profitability is one of the key determinants of investment. Therefore, the rate of return on investment in a host economy affects the investment decision. Further, the marginal product of capital is equal to the return on capital. However, capital-scarce countries have higher returns (Alavinasab, 2013; Asiedu, 2002).

Edwards (1990), Jaspersen et al. (2000) and Asiedu (2002) employed the inverse of per capita income as a measure for return on investment, and their results showed that GDP per capita was inversely related to FDI. In contrast, Schneider and Frey (1985) revealed a positive relationship between GDP and FDI. It can be argued that GDP provides better prospects for foreign direct investment in the host country.

H7. Investment return has a positive impact on FDI inflows. 


\subsection{Governance}

In recent years, discussions have been held on international development and political discourse within the framework of good governance, and, for this reason, the attraction of foreign investment is an important factor for the good functioning of the country's market. Thus, governments seeking to attract foreign direct investment should create favourable conditions for multinational corporations. On the other hand, the FDI decision-making process for investors and foreign organisations is valuable in understanding the status of governance indicators in terms of transparency of administrative processes, reducing corruption and the peaceful environment (World Bank, 2006). Morisset (2000) draws the conclusion that an increase in administrative costs due to corruption and bad governance will reduce FDI inflows. Moreover, other studies argue that political and institutional factors are necessary to encourage FDI to the developing countries (e.g., Stein and Daude, 2001; Stevens, 2000).

Samimi and Ariani (2010) employed three governance indicators, including political stability, corruption control and the rule of law for investigating the impact of a better quality of governance on FDI inflows in the MENA region. They found that these indicators have a positive impact on FDI inflows and improve governance.

In another study, Mengistu and Adhikary (2011) employed six indicators of good governance that included political stability, government effectiveness, and rule of law, the absence of violence and control of corruption. Their result revealed that these six indicators had an impact on FDI inflows in 15 Asian countries and, therefore, could increase the attraction of FDI.

H8. Governance has an impact on FDI inflows.

\section{SANCTIONS}

Sanctions are an economic weapon for countries to fulfil their foreign policy goals. Over the last century, various countries imposed many international economic sanctions against other nations (Hufbauer et al., 2007). Thus, Eaton and Engers (1992), Elliot and Hufbauer (1999), Davis and Engerman (2003), and van Bergeijk (2009) suggested various theoretical frameworks to explain how sanctions work.

After the Iranian revolution and after the hostage-taking of US agents in 1979, the United States stopped its economic and diplomatic ties with Iran, banned the import of Iranian oil and froze approximately $\$ 11$ billion of its assets (Krauss, 2015). In 1996, the US government approved the Iranian-Libyan Sanctions Act (ILSA), which prohibited US (and non-US) companies from investing and trading more than \$20 million annually with Iran. Since 2000, items such as pharmaceuticals and medical equipment have been excluded from these sanctions (DeRosa and Hufbauer, 2012).

Iran's nuclear programme has been debated over suspicions of its intentions since 2006. The UN Security Council has imposed sanctions on selected companies associated with the nuclear programme, which would cause the country's economic 
isolation (Gheissari, 2009), in particular, targeted sanctions on nuclear, missile and many military exports to Iran, and investment in oil, gas, and petrochemicals, the export of refined petroleum products, financial transactions, banks, shipping, and insurance. In 2012, the European Union made its sanctions harder by joining the US oil embargo against Iran (Solomon, 2014). Furthermore, the last round of sanctions can bring about $\$ 50$ billion in lost oil revenue annually to Iran.

Over the years, sanctions have serious consequences for the Iranian economy and people. The United States has made many international efforts to convince Western governments of the threat of Iran's uranium enrichment programme and the development of nuclear weapon capability. However, Iran has denied it and believes its nuclear programme is for civilian purposes, including power generation and medical purposes (Guzman, 2013). Monetary factors also cause problems, as sanctions cause a sharp fluctuation in the value of the Iranian Rial. Moreover, a weak currency will make imports more expensive, and affect everything that is based on Rial, including wages, stocks, homes, pensions, and gold. Thus, businesses also can hardly determine the price of goods and the value of their services. However, there is difference between (i) the sanctions imposed on imports of nuclear-related products in 2006 and 2007, (ii) the sanctions imposed on non-oil exports in 2008, and (iii) the financial sanctions (such as SWIFT, Banking) against Iran in 2012 (Haidar, 2015).

Therefore, sanctions have been categorised based on their effect on the Iranian economy: 1) Political sanctions: block the assets of individuals who are determined to support international terrorism. The list includes dozens of Iranian individuals and institutions, including banks, defence contractors. The Iran-Iraq NonProliferation Treaty (1992) prohibits anyone or entity that contributes to Iran's nuclear, chemical or biological weapons. 2) Trade sanctions: The United States bans sanctions that most US companies are banned from trading or investing in Iran until 1995. Although it slowed down in 2000, it almost finished decades later. The Obama administration has taken exception to the sanctions on the sale of consumer telecommunications equipment and software. 3) Energy sanctions: The US's main focus is on reducing Iran's oil revenues. In this way, the pressure on the nonproliferation of nuclear weapons will increase. Before 2012, oil exports accounted for half the revenue of the Iranian government and made up one-fifth of the GDP. Extraterritorial sanctions target foreign companies that provide services or participate in investing in energy activities, including oil and gas and petrochemicals, supplying equipment used in oil refining as well as oil export activities, such as shipbuilding, port operations, and shipping insurance.

4) Financial and banking sanctions: US sanctions by the Treasury Department have sought to isolate Iran from the international financial system. Thus, foreign financial institutions, or subsidiaries that deal with banned banks prevented from conducting transactions with US dollars. In late 2011, the United States also prevented importers of oil imports to make payment through the Central Bank of Iran. Other aspects of the financial sanctions include limiting Iranians' access to foreign currencies so that the funds from oil exports can only be used for bilateral trade with the buyer country or access to humanitarian goods. Askari et al. (2002) believe that financial sanctions policies that are less discussed have had more 
important and long-term effects. Financial sanctions and policies that can be adequately measured include a restriction on export financing, limiting the IMF and World Bank financing, reducing commercial financing, restricting Iran's debtrescheduling efforts, and reducing FDI inflows (especially in the energy sector). However, effects that are not measurable include air travel restrictions, tourism, and risk assessment of Iran, which in turn affect foreign direct investment in non-energy sectors and other joint ventures. Many international companies are also reluctant to do business with Iran because of the fear of losing access to larger Western markets.

The United Nations Security Council Resolution (No. 2231) was adopted on 20 July 2015. Therefore, a plan was made to suspend and eventually abolish United Nations sanctions with provisions to re-impose UN sanctions in case of nonperformance by Iran. Under the Joint Comprehensive Plan of Action (JCPOA), to suspend and eventually lift UN sanctions, almost immediately the EU and the United States announced that sanctions already imposed on Iran were lifted. In practice, all sanctions imposed by the EU were removed. Some US sanctions, but not all of them, were lifted. Between \$ 100 billion and \$ 150 billion of Iranian financial assets were released. Besides, trade sanctions that limited Iran's oil exports, as well as restrictions on imports of many goods, were also lifted.

Hence, it is expected that the lifting of the EU sanctions would have the greatest impact on macroeconomic policy in Iran and elsewhere, because oil accounts for 64 percent of Iran's export earnings, and Iran has a relatively high share (8 percent) of total world exports. Furthermore, the removal or reduction of inspections on imports and exports of Iran were imposed as part of the regime of sanctions. Moreover, transport costs are expected to decrease in trade with Iran. Furthermore, due to the fact that the US and other partners have abolished restrictions on financial transactions services, Iran's import of financial services is expected to increase (Ianchovichina et al., 2016). Nevertheless, on 8 May 2018, the United States announced its withdrawal from the JCPOA, also known as the "Iran nuclear deal".

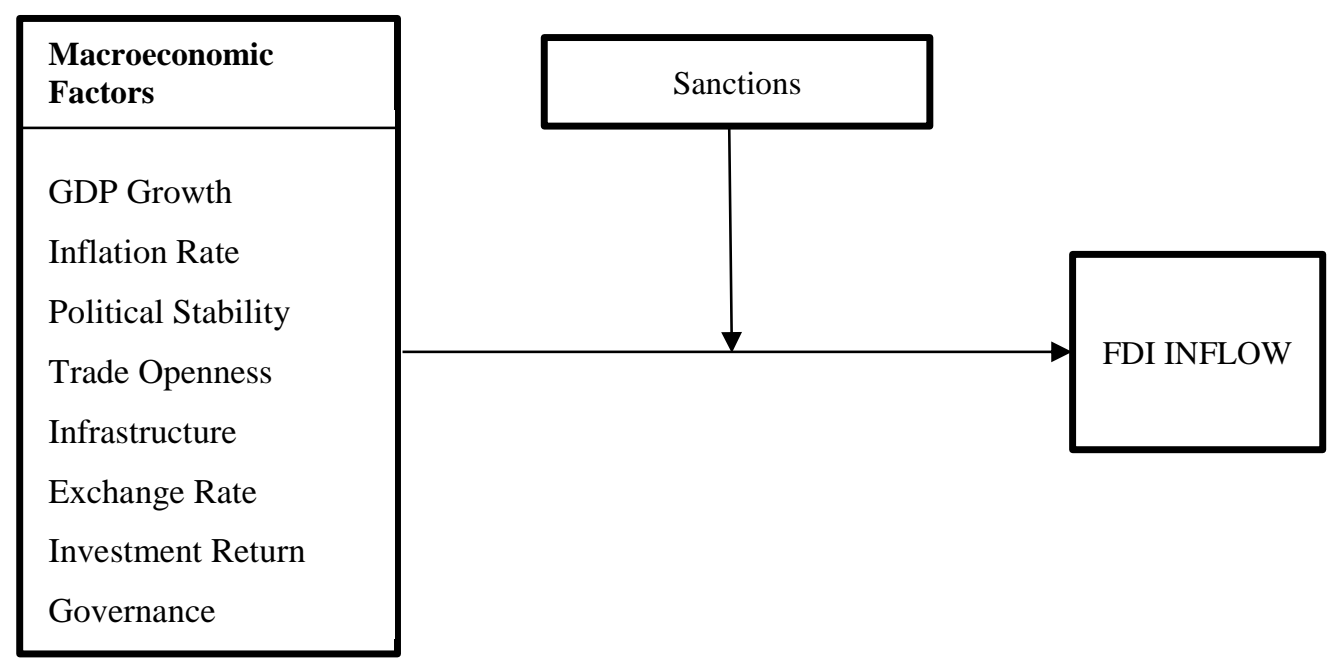

Fig. 2. Research framework. 
However, we can state that in better political circumstances, such as non-US sanctions, it is likely to have much higher FDI.

H9. Sanctions moderate the relationship between macroeconomic factors and the FDI inflow in Iran.

The research framework in Fig. 2 shows the impact of selected macroeconomic factors on FDI inflows. However, we expect that the sanction has a moderation role in the expected relationship of macroeconomic variables with the FDI inflows in Iran.

\section{DATA AND METHODOLOGY}

The study tries to identify the determinant factors of foreign direct investment in the Iranian economy based on the secondary data sources for the period of 19912014. We seek to explain inward investment in the country based on a number of macroeconomic variables such as infrastructure, trade openness, governance, growth rate, political stability, inflation, and exchange rates. These variables have already been used in literature as factors that may influence FDI inflows. Since international sanctions have made some restrictions on Iran's economy and those may affect FDI as well as macroeconomic factors, we study the moderating effect of sanctions on FDI during the above-mentioned period. The data are taken on an annual basis from various sources, including UNCTAD statistics, the World Bank Indicator reports, Political Risk Services (PRS), Worldwide Governance Indicators (WGI), the International Telecommunication Union (ITU) database as well as Iran's Central Bank reports.

FDI INFLOW is the actually used FDI. GDP GROWTH is the real gross domestic product (GDP) growth rate. The growth rate can be representation of the wealth of a country. The good INFRASTRUCTURE will increase investment productivity and encourage FDI inflows (Asiedu, 2002). However, infrastructure measured by the number of mainline telephones per 100 population is used to proxy for the level of infrastructural development. GOVERNANCE measures the level of governance and institutional quality in a country. The data regarding the variable is taken from the World Bank Website and the Worldwide Governance Indicators. However, we study the impact of the six governance indicators on FDI inflow measured by the KKM Index, a broad governance measure developed by Kaufmann, Kraay, and Mastruzzi (2009) which consists of the average of six indicators, including voice and accountability, political stability and absence of violence, regulatory quality, government effectiveness, rule of law, and control of corruption. Trade OPENNESS represents the degree of openness of a country to international trade and foreign investors. It is measured by the ratio of total imports and exports over gross domestic product. Further, it is recognised as a key factor in attracting FDI to the country (e.g., Cleeve et al., 2015; Sahni, 2012; Sahoo, 2006). INFLATION Corresponding to the Consumer Price Index (CPI) changes in years. It is a proxy for macroeconomic stability. Therefore, it shows the government's overall ability to manage the economy. The high inflation rate creates uncertainty about the assets and liabilities of investors. Therefore, companies have less incentive to invest in high inflation countries (Abdellah et al., 2012). Thus, inflation 
hurts FDI. POLITICAL Stability is measured by ICRG, which is the measure of democracy published in the International Country Risk Guide (ICRG). Political Risk Services (PRS) publish the data; it reflects the extent to which elections are free and fair and the degree to which the government is accountable to its electorate. However, the index ranges from one to six, a higher score of which implies more democracy and accountability (Asiedu and Lien, 2011). EXCHANGE Rate is the time-variant real exchange rate. It represents competitiveness in international trade and the extent of market liberalization in the foreign exchange market (Yao and Zhang, 2001). The depreciation of a host country's currency makes the host country's assets become interesting investment targets for foreign investors. In order to measure the INVESTMENT Return, we follow Jaspersen et al. (2000) and Asiedu (2002) to use the inverse of per capita income as a proxy for return on investment. Thus, investing in countries with higher per capita income should have a lower return, and, therefore, real GDP per capita is inversely related to FDI inflow.

SANCTIONS have been categorised based on their effect on the Iranian economy: 1) Political sanctions: frozen assets of entities determined to be supporting international terrorism, including individuals and institutions, defence contractors; and any person or entity that assists Iran in weapon development. 2) Trade sanctions: an embargo that prohibits most firms from trading with or investing in Iran. 3) Energy sanctions: sanctioning services and investment related to the energy sector, including investment in oil and gas fields, sales of equipment, and participation in activities related to oil and gas export. 4) Financial sanctions: isolating Iran from the international financial systems such as a central bank, credits and swift system.

However, to measure the SANCTIONS variable, we have first explored all sanctions against Iran. However, from 1990 to 2014, about 25 sanctions by the United States (US), 6 sanctions by the European Union (EU) and 9 sanctions by the United Nations Security Council (UN) were imposed against Iran. Then, we have listed the sanctions in a form and asked twenty economists to score these sanctions, and determined the significance of each sanction based on its intensity and impact on Iran's economy. As a result, financial boycotts found to be the most effective and toughest sanctions on Iran, followed by energy sanctions, trade and, finally, by political sanctions that have less impact on the Iranian economy. Therefore, we have calculated the value of sanction effects each year by weighting them based on the type and the number of sanctions imposed for each year. For example, in 2006, there were three political sanctions and one trade sanction; therefore, the value of the sanction variable for this year was $0.4(2 \times 0.1+1 \times 0.2)$. Moreover, since previous sanctions were still in place, the value of the previous year was added to the value of sanctions in the year 2006.

Having established co-integration among the variables, we have investigated their impact on the FDI inflows. For this purpose, we propose an Ordinary Least Squares (OLS) method to estimate long-term relationships. 


\section{RESULTS}

We have used the Unit Root Test and Augmented Dickey-Fuller (ADF) method in this study. As shown in Table 2, the dependent variable of FDI inflows and the variety of macroeconomic variables are stationary.

Table 2. ADF Unit Root Test Results Using the Trend and Intercept

\begin{tabular}{|c|c|c|c|c|c|c|c|c|c|}
\hline \multirow[t]{2}{*}{ Variables } & \multicolumn{2}{|c|}{ Level } & \multicolumn{2}{|c|}{ 1st Diff } & \multicolumn{2}{|c|}{ 2nd Diff } & \multicolumn{2}{|c|}{ 3rd Diff } & \multirow[t]{2}{*}{ Lag } \\
\hline & $t$ & Prob & $t$ & Prob & $t$ & Prob & $t$ & Prob & \\
\hline FDI & -2.533 & 0.3107 & -4.237 & 0.0152 & & & & & 0 \\
\hline GROW & -3.894 & 0.0073 & & & & & & & 0 \\
\hline CPI & 2.638 & 0.9995 & 1.976 & 1.000 & 1.529 & 0.9999 & -4.391 & 0.0150 & 6 \\
\hline ICRG & -3.273 & 0.0993 & -2.681 & 0.0938 & -6.067 & 0.0005 & & & 3 \\
\hline OPEN & -2.655 & 0.2619 & -2.892 & 0.0624 & -5.812 & 0.0001 & & & 1 \\
\hline INFR & 2.088 & 0.9997 & -3.798 & 0.0374 & & & & & 2 \\
\hline $\mathrm{EXCH}$ & -1.863 & 0.6389 & -2.191 & 0.2148 & -5.566 & 0.0002 & & & 1 \\
\hline INVS & -1.865 & 0.3416 & -5.463 & 0.0002 & & & & & 0 \\
\hline GOVE & -3.430 & 0.0729 & -4.566 & 0.0018 & & & & & 1 \\
\hline SANC & 0.942 & 0.9996 & -3.274 & 0.0289 & & & & & 0 \\
\hline
\end{tabular}

FDI: FDI Inflow; GROW: GDP Growth; CPI: Consumer Price Index as a proxy for inflation; ICRG: International Country Risk Guide as a proxy for political stability; OPEN: Trade Openness; INFR: Infrastructure; EXCH: Exchange rate; INVS: Investment return; GOVE: Governance; SANC: Sanctions.

Table 3. Correlations

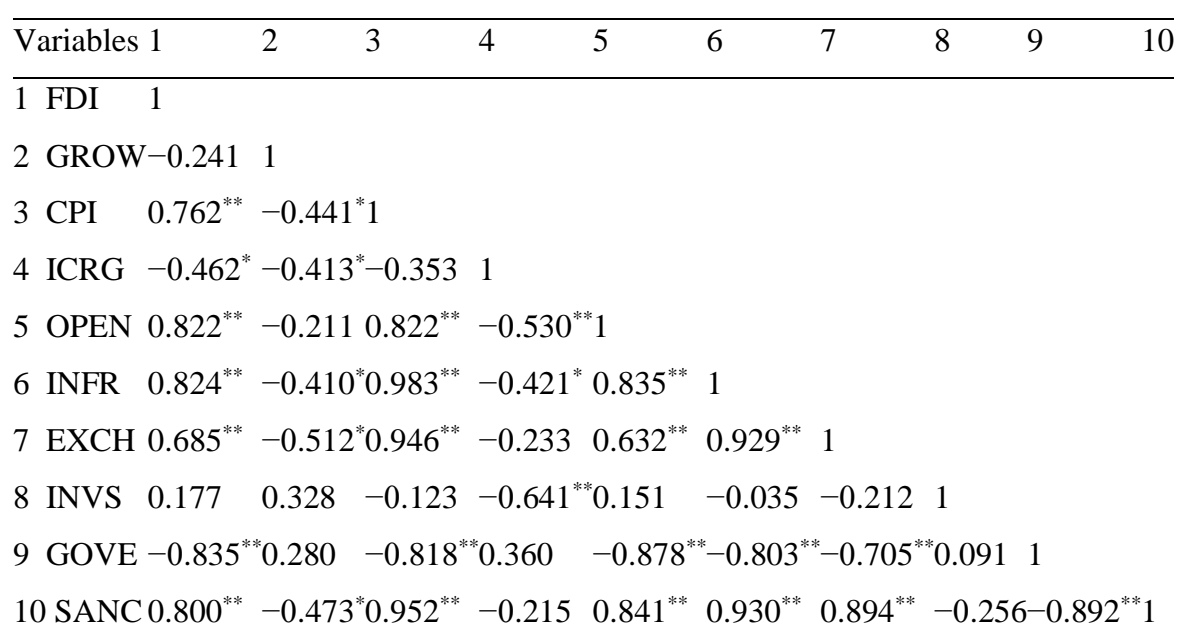

** Correlation is significant at the 0.01 level

* Correlation is significant at the 0.05 level 
Table 4. Linear Regression (Effect of Sanctions on Macroeconomic Factors)

\begin{tabular}{|c|c|c|c|c|c|c|c|c|c|}
\hline Variable & $\begin{array}{c}\text { GDP } \\
\text { Growth }\end{array}$ & $\begin{array}{c}\text { Inflation } \\
\text { Rate }\end{array}$ & $\begin{array}{l}\text { Political } \\
\text { Stability }\end{array}$ & $\begin{array}{c}\text { Trade } \\
\text { Openness }\end{array}$ & $\begin{array}{c}\text { Infra- } \\
\text { structure }\end{array}$ & $\begin{array}{c}\text { Exchange } \\
\text { Rate }\end{array}$ & $\begin{array}{c}\text { Investment } \\
\text { Return }\end{array}$ & Gove & $\begin{array}{c}\text { FDI } \\
\text { Inflow }\end{array}$ \\
\hline Sanc & $\begin{array}{c}-0.459 * * \\
(-2.422)\end{array}$ & $\begin{array}{c}0.964 * * * \\
(16.943)\end{array}$ & $\begin{array}{c}-0.299 \\
(-1.470)\end{array}$ & $\begin{array}{c}0.798 * * * \\
(6.215)\end{array}$ & $\begin{array}{c}0.971 * * * \\
(19.223)\end{array}$ & $\begin{array}{c}0.814 * * * \\
(6.563)\end{array}$ & $\begin{array}{l}-0.215 \\
(-1.033)\end{array}$ & $\begin{array}{c}-0.827 * * * \\
(-6.903)\end{array}$ & $\begin{array}{c}0.789 * * * \\
(6.018)\end{array}$ \\
\hline R Square & 0.211 & 0.929 & 0.089 & 0.637 & 0.944 & 0.662 & 0.046 & 0.684 & 0.622 \\
\hline $\operatorname{Adj} . R^{2}$ & 0.175 & 0.926 & 0.048 & 0.621 & 0.941 & 0.647 & 0.003 & 0.670 & 0.605 \\
\hline
\end{tabular}

The number in parenthesis is $t$-value.

Table 5. OLS Regression

\begin{tabular}{|c|c|c|c|c|c|c|}
\hline \multirow[b]{2}{*}{ Variable } & \multicolumn{2}{|l|}{ Model (1) } & \multicolumn{2}{|c|}{ Model (2) } & \multicolumn{2}{|c|}{ Model (3) } \\
\hline & Predictors & $T$ value & Moderated & $T$ value & teractions & $T$ value \\
\hline Constant & & -3.140 & & -2.141 & & -0.050 \\
\hline GDP growth & 0.056 & 0.503 & 0.060 & 0.531 & -0.023 & -0.149 \\
\hline Political stability & 0.113 & 0.693 & 0.077 & 0.455 & $-0.893^{*}$ & -1.849 \\
\hline Infrastructure & $1.968 * * *$ & 4.522 & $1.902 * * *$ & 4.253 & 1.130 & 1.285 \\
\hline Governance & $-0.440 * *$ & -2.118 & $-0.406 *$ & -1.896 & 0.167 & 0.437 \\
\hline Exchange rate & $0.393^{* *}$ & 2.275 & 0.260 & 1.090 & 0.297 & 0.375 \\
\hline Investment return & $0.238 *$ & 2.063 & $0.300 *$ & 2.162 & 0.318 & 1.453 \\
\hline Inflation rate & $-1.818 * * *$ & -4.226 & $-1.988 * * *$ & -4.129 & -1.722 & -0.673 \\
\hline Trade openness & 0.070 & 0.355 & -0.086 & -0.314 & -0.333 & -0.440 \\
\hline Sanctions & & & 0.521 & 0.823 & 1.018 & 1.206 \\
\hline GDP*SANC & & & & & -0.489 & -1.301 \\
\hline ICRG*SANC & & & & & -1.044 & -1.496 \\
\hline INFR*SANC & & & & & 1.419 & 0.206 \\
\hline GOVE*SANC & & & & & -0.661 & -1.769 \\
\hline EXCH*SANC & & & & & $-2.402 *$ & -1.994 \\
\hline INVS*SANC & & & & & 0.117 & 0.627 \\
\hline CPI*SANC & & & & & 2.158 & 1.020 \\
\hline OPEN*SANC & & & & & -0.989 & -1.619 \\
\hline $\begin{array}{l}R \text { Square } \\
\text { Adjusted } R\end{array}$ & 0.934 & & 0.937 & & 0.97 & \\
\hline Square & 0.899 & & 0.896 & & 0.92 & \\
\hline$R$ Square change & 0.934 & & 0.003 & & 0.04 & \\
\hline$F$ statistic & $26.505^{* *}$ & & $23.127 * * *$ & & 18.458 & ** \\
\hline
\end{tabular}

The Durbin-Watson Statistic has been used to test for the presence of serial correlation among the residuals. The value of Durbin-Watson for Model 3 is 1.879, approximately equal to two, indicating no serial correlation.

Table 4 demonstrates the effect of sanctions on macroeconomic factors. The result of simple linear regression reveals that sanctions have a positive significant impact on the inflation rate $(t=16.943)$, trade openness $(t=6.215)$, infrastructure $(t=19.223)$, and exchange rate $(t=6.563)$. Nevertheless, the international sanction against Iran has a negative significant impact on GDP growth $(t=-2.422)$ and governance $(t=-6.903)$. Furthermore, sanctions have a positive impact on FDI inflows in Iran. 
The regression results in Table 5 show the effect of the macroeconomic variable on foreign direct investment in Iran. As expected, infrastructure is very significant in FDI. However, previous studies (e.g., Jafarnejad et al., 2011; Ramirez, 2009; Asiedu, 2005) indicate a positive significant relationship between infrastructure and FDI. The governance of the host country has a negative significant impact on attracting FDI into Iran. It means a 1 percent depreciation in the level of governance causes FDI to increase by approximately 0.44 . Thus, our result is inconsistent with other studies (e.g., Mengistu and Adhikary 2011; Samimi and Ariani, 2010; Globerman and Shapiro, 2002). Moreover, the results illustrate that the exchange rate is significant in explaining changes in FDI. The finding is in line with other studies (e.g., Nurudeen, Auta, \& Wafure, 2011; Adam \& Tweneboah, 2009; Kaya \& Yilmaz, 2003). Accordingly, they found a positive impact of exchange rate on FDI inflows. However, others such as Masayuki and Ivohasina (2005) found that exchange rate depreciation might encourage the inflow of foreign direct investment to the host country.

Furthermore, the results reveal that trade openness of the economy and political stability are statistically insignificant but positively related to foreign direct investment. However, the result is in the context of developed countries (Jimenez et al., 2011; Bitzenis et al., 2009). Similarly, the results show that GDP growth has an insignificant effect on foreign direct investment in Iran. This is consistent with Abdel-Rahman's (2002) results that indicate that GDP growth rate has a positive but mainly insignificant impact on FDI in Saudi Arabia.

Further, the estimation also illustrates that the inflation rate in Iran has a significant negative effect on FDI inflows. Some studies (e.g., Bissoon, 2012; Parajuli \& Kennedy, 2010; Bouoiyour, 2007; Asiedu, 2006) reveal that high inflation will hinder FDI inflows. Furthermore, inflation has a positive relationship with FDI. In contrast, some studies (e.g., Shahzad \& Al-Swidi, 2013; Parajuli \& Kennedy, 2010) reveal a negative relationship between inflation and FDI.

Another result of estimation is that the investment return of the economy has a positive relation with FDI inflows. The positive impact of investment return on FDI reflects the situation in Iran's oil and gas sectors that have continued to attract more foreign investment regardless of the imposed sanctions. Furthermore, the results have shown a negative effect of governance on FDI inflows; therefore, our OLS regression results are consistent with the empirical literature (e.g., Kuzmina et al. 2014). The worse the governance quality, the less foreign investment we observe in Iran. A common explanation of this evidence would be that corruption and potential pressure create uncertainty for investors in terms of their future cash flows, acting as an additional tax and increasing the risks of business capture, thereby decreasing the attractiveness of a particular region (Kuzmina et al. 2014). Moreover, the result in the model 3 shows that when the sanctions moderate the relationship between macroeconomic determinants and FDI, political stability and exchange rate have a significant negative impact on FDI inflow in Iran. 


\section{DISCUSSION AND CONCLUSIONS}

Following the literature, our research examines the known macroeconomic factors from the literature in the context of Iran, which has a unique context, quite different from those of other countries, given its unique geographical and historical situation and especially the unique international sanctions faced by the country. Comprehensive research into the established FDI macroeconomic factors in Iran in the light of the unique international sanctions would, therefore, throw new light on the subject, particularly, the impact of international sanctions on incoming FDIs in a country. This is obviously an important issue to post-revolutionary as well as postsanctions Iran.

Our findings demonstrate that most of the macroeconomic factors have an impact on the FDI inflow into Iran. Gross \& Trevino (1996) state that countries that have high levels of GDP growth are highly inclined to increase foreign direct investment flows by attracting trust from multinational corporations and encouraging them to invest. However, according to Biglaiser \& DeRouen (2011), more economic development attracts investors and they believe that the potential market is for a high return on investment. Further, a positive relationship between infrastructure and FDI implies that the development of infrastructure will increase inflows of FDI to Iran (Alavinasab, 2013). FDI investors usually look for a location that has suitable infrastructures such as roads, transportation, and telecommunications. Investing in developed host markets can reduce investors' production costs and then increase their profits. Foreign investors in Iran are more focused on energy sectors, including oil and gas, petrochemicals, as well as telecommunications, car manufacturing, and mine industries. Javidan \& Dastmalchian (2003) have, however, indicated that there are two internal movements with totally different thoughts to determine the direction of the future of the country: those who are not opposed to development and consider it as a means to achieve religious goals; and those who feel that the survival of Islam and the progress of Iran require a more modern perspective. However, a continued confrontation between the two streams has caused political instability and turmoil and has slowed the progress of the country.

Furthermore, our finding indicates that sanctions have a significant impact on governance. This implies that sanctions may lead to corruption and bad governance, which increase administrative costs and, therefore, reduce FDI inflows. However, governance affects the security of property rights, transparency, and legal process. Furthermore, the results indicate a negative effect of sanctions on GDP. This may be due to embargos on Iran's oil and gas, which reduce oil exports. Along with the dependency on real GDP growth in Iran is oil. Therefore, sanctions have had a significant impact on Iran's economic growth in recent years due to an increase in the severity level of sanctions.

Additionally, sanctions have a positive impact on the inflation rate and exchange rate in Iran. When international financial sanctions hampered access to oil revenues, Iran experienced a currency crisis that led to a sharp decline in the Rial. On the other hand, the government faced a problem to increase foreign currencies for its import needs, since the demand for foreign currencies exceeded 
supply, which in turn led to a depreciation of the Rial. Moreover, sanctions are not the major cause of the exchange rate crisis in recent years.

Our results indicate that sanctions do not have a significant moderating role in the relationship between macroeconomic factors and foreign direct investment. Surprisingly, international sanctions have a positive relationship with FDI inflows in Iran. It means that, despite the sanctions, some multinational companies have realised the opportunities in the Iranian market as a developing economy and have invested in less-under-threatened industries. Moreover, the special conditions of Iran during the years after the Iraq-war, including the abundance of natural resources, geographic location, the young and educated population; and the growing economy, have set the country as one of the objectives of direct foreign investment. However, over the years, sanctions have serious consequences for the people and the economy of Iran. Nevertheless, the impact of sanctions is often denied in the Iranian press.

Iran has taken measures to circumvent sanctions, in particular through using barter trade and with the help of front countries or companies. Moreover, in response to the sanctions, the Iranian government has backed a "resistance economy", such as more domestic use of oil due to limited export markets and the use of alternative industries.

After the agreement between Iran and the P5+1 in 2015, the so-called postsanction era has begun in Iran. Moreover, sanctions relief will affect Iran's economy in four main ways: (1) the release of Iran's frozen funds abroad by 2015, which is over $\$ 100$ billion; (2) the lifting of the sanctions against Iran's oil exports; (3) allowing foreign companies to invest in oil and gas, automobiles, hotels and other parts of Iran; (4) permitting trade with the rest of the world and access to a global banking system, such as SWIFT. However, with lifting sanctions, prospects are brighter for Iran, with new opportunities arising in oil and gas, and investment in manufacturing industries. Iran's government has established several incentive programs in order to encourage foreign companies to invest in Iran.

In addition, providing incentives will attract more foreign investment, create jobs, provide access to new technologies and result in other social and economic benefits. However, Cleeve (2008) argues that incentive costs outweigh their benefits, and he believes that improvements in local infrastructure, political stability, and macroeconomic stability are better tools for stimulating foreign direct investment inflows. Nevertheless, in order to maximise the benefits of sustainable development through FDI (and other external sources of finance), policymakers must be mindful of minimising risks. Therefore, through good governance, stakeholder participation, creating relevant local capacities, increasing absorption capacity (entrepreneurship, technology, skills, and communication), and creating effective standards and regulatory framework, risks can be minimised (UNCTAD, 2015).

Haidar (2015) asserts that while export sanctions against Iran have not reduced total exports, they have increased export costs. If the goal is to reduce total exports, export sanctions may not be effective in global economy. He argues that sanctions may be less effective in a globalised world because exporters can shift their exports from an export destination to the other. Thus, the idea that a country can impose 
trade sanctions on another does not necessarily prove the effectiveness of such sanctions.

The Iranian government must strive to make more deregulation in its economy to attract more foreign direct investment. It is true as the inflow of foreign direct investment has increased since the introduction of the investment incentive programme in 2005. The sanctions on Iran and the current crisis in the Middle East region have been a major obstacle to the instability of Iran's economy. Thus, the restoration of peace in the region and the removal of sanctions will encourage more foreign investment to Iran. Furthermore, Iran needs to increase the competitiveness of the investment environment by investing more in infrastructure and ultimately increasing the inflow of FDI. Finally, all of the above-mentioned considerations should be accompanied by ongoing reforms in the Iranian economy.

\section{REFERENCES}

Abdellah K., Nicet-Chenaf D. and Rougier E. (2012). FDI and macroeconomic volatility: a close-up on the source countries. Cahiers du GREThA, 2012-21. Available from: https://pdfs.semanticscholar.org/01f1/5a8bc126ee8ebafa0a31ba9e864c102433eb.pdf

Abdioglu, N., Khurshed, A., \& Stathopoulos, K. (2013). Foreign institutional investment: Is governance quality at home important? Journal of International Money and Finance, 32(1), 916-940. https://doi.org/10.1016/j.jimonfin.2012.08.001

Alavinasab, S. M. (2013). Determinants of Foreign Direct Investment in Iran. Int. J. Academic Research in Business and Social Sciences, 3(2), 258-270.

Alcantara, L. L., \& Mitsuhashi, H. (2012). Make-or-Break Decisions in Choosing Foreign Direct Investment Locations. Journal of International Management, 18(4), 335-351. https://doi.org/10.1016/j.intman.2012.07.002

Alfaro, L., Chanda, A., Kalemli-Ozcan, S., \& Sayek, S. (2004). FDI and economic growth: The role of local financial markets. Journal of International Economics, 64(1), 89-112. https://doi.org/10.1016/S0022$\underline{1996(03) 00081-3}$

Allen \& Overy LLP. (2006). Foreign direct investment in Central and Eastern Europe. Retrieved from http://www.springerlink.com/index/63Q53V5T705K6JT7.pdf

Amal, M. (2016). Foreign Direct Investment in Brazil. Post-Crisis Economic Development in Emerging Markets. Elsevier, 63-119. https://doi.org/10.1016/B978-0-12-802067-8.00003-7

Anwar, S., \& Nguyen, L. P. (2011). Foreign direct investment and trade: The case of Vietnam. Research in International Business and Finance, 25(1), 39-52. https://doi.org/10.1016/j.ribaf.2010.05.004

Asiedu, E., \& Lien, D. (2011). Democracy, foreign direct investment, and natural resources. Journal of International Economics, 84(1), 99-111. https://doi.org/10.1016/j.jinteco.2010.12.001

Askari, H., Forrer, J., Teegen, H., \& Yang, J. (2002). Economic sanctions and US international business interests. Banca Nazionale del Lavoro Quarterly Review, Banca Nazionale del Lavoro, 55(220), 55-69.

Azam, M., \& Lukman, L. (2010). Determinants of Foreign Direct Investment in India, Indonesia and Pakistan: A quantitative Approach. Journal of Managerial Sciences, 4(1), 31-44.

Biglaiser, G., \& DeRouen, K. (2011). How soon is now? The effects of the IMF on economic reforms in Latin America. The review of international organizations, 6, 189-213. https://doi.org/10.1007/s11558-011-9123-8

Bissoon, O. (2012). Can Better Institutions Attract More Foreign Direct Investment? Evidence from Developing Countries. International Research Journal of Finance and Economics, 82, 142-158.

Bitzenis, A., Tsitourasb, A., \& Vlachosa, V. A. (2009). Decisive FDI Obstacles as an Explanatory Reason for limited FDI Inflows in an EMU Member State: The Case of Greece. The Journal of Socio-Economics, 38, 691-704.

Blonigen, B., \& Ma, A. C. (2011). Please Pass the Catch-Up: The Relative Performance of Chinese and Foreign Firms in Chinese Exports. China's Growing Role in World Trade Eds. Feenstra R.C. \& Wei S-J. University of Chicago Press, 475-509.

Bouoiyour, J. (2007). The Determining Factors of Foreign Direct Investment in Morocco. Saving and Development, 31(1), 91-106. 
Chan, M. W. L., Hou, K., Li, X., \& Mountain, D. C. (2014). Foreign direct investment and its determinants: A regional panel causality analysis. Quarterly Review of Economics and Finance, 54(4), 579-589. https://doi.org/10.1016/j.qref.2013.07.004

Chang, S. C., \& Boontham, W. (2017). Post-privatization speed of state ownership relinquishment: Determinants and influence on firm performance. North American Journal of Economics and Finance, 41, 82-96. https://doi.org/10.1016/j.najef.2017.04.001

Ciesielska, D., \& Kołtuniak, M. (2017). Outward foreign direct investments and home country's economic growth. Physica A: Statistical Mechanics and Its Applications, 482, 127-146. https://doi.org/10.1016/j.physa.2017.04.057

Clare G. \& Gang, N. (2010). Exchange Rate and Political Risks, Again. Emerging Markets Finance and Trade, 46(3), 46-58. https://doi.org/10.2753/REE1540-496X460303

Cleeve, E. A., Debrah, Y. A. W., \& Yiheyis, Z. (2015). Human Capital and FDI Inflow: An Assessment of the African Case, 74, 1-14. https://doi.org/10.1016/j.worlddev.2015.04.003

Development, F. F. O. R. (2015). Financing for development - FDI can be an important source of external development financing for LDCs, LLDCs and SIDs, (20), 1-10.

Economic Cooperation Organization (ECO) Secretariat (2010). Statistics, Retrieved September 28, 2010.

Elheddad, M. M. (2017). What determines FDI inflow to MENA countries? An empirical study on Gulf countries: Sectoral level analysis. Research in International Business and Finance, 44, 332-339. https://doi.org/10.1016/j.ribaf.2017.07.101

Ghahroudi, M. R. (2011). Ownership Advantages and Firm Factors Influencing Performance of Foreign Affiliates in Japan. International Journal of Business and Management, 6(11), 119-137. https://doi.org/10.5539/ijbm.v6n11p119

Ghahroudi, M. R., Turnbull, S., \& Hoshino, Y. (2010). Assets growth, foreign ownership and type of industry in multinational companies. International Business Research, 3(4), 244-259. https://doi.org/10.5539/ibr.v3n4p244

Gheissari, Ali (2009). Contemporary Iran: economy, society, politics. USA: Oxford University Press. pp. 7-8 (Paperback edition). ISBN 0-19-537849-0. https://doi.org/10.1093/acprof:oso/9780195378481.001.0001

Global Investment Trends Monitor (2015). Financing for development - FDI can be an important source of external development financing for LDCs, LLDCs and SIDs, United Nations, (20), 1-10.

Goldman Sachs, (2011). The N-11: More Than an Acronym". Goldman Sachs, Retrieved February 6, 2011.

Golub, S. S. (2003). Measures of Restrictions on Inward Foreign Direct Investment for OECD Countries. OECD Economic Studies, 2003(1), 85-116. https://doi.org/10.1787/eco_studies-v2003-art3-en

Grosse, R., \& Trevino, L. J. (1996). Foreign Direct Investment in the United States: An Analysis by Country of Origin. Journal of International Business Studies, 27(1), 139-155. https://doi.org/10.1057/palgrave.jibs.8490129

Guzman, Timothy A. (2013). New Economic Sanctions on Iran, Washington's Regime Change Strategy. Global Research. Retrieved 5 May 2013.

Haidar, J. I. (2015). Sanctions and Export Deflection: Evidence from Iran. Working Paper, Harvard University OpenScholar.

Ianchovichina E., Devarajan Sh. \& Csilla Lakatos C. (2016). Lifting Economic Sanctions on Iran Global Effects and Strategic Responses. Policy Research Working Paper 7549, Middle East and North Africa Region, World Bank eLibrary. https://doi.org/10.1596/1813-9450-7549

International Monetary Fund (2014). World Economic Outlook Database (Iran). Retrieved February 16, 2015.

Javidan, M., and Dastmalchian A. (2003). Culture and leadership in Iran: The land of individual achievers, strong family ties, and powerful elite. Academy of Management Executive 17(4), 127-142. https://doi.org/10.5465/ame.2003.11851896

Jimenez, A., de la Fuente, J. M., \& Duran, J. J. (2011). Is there an East-West Structure in the Location of FDI in Europe? The role of institutions and political risk. research in economics and business: Central and Eastern Europe, 3, 5-23.

Kahai, S. K. (2011). Traditional and non-traditional determinants of foreign direct investment in developing countries. Journal of Applied Business Research, 20(1). https://doi.org/10.19030/jabr.v20i1.2194

Kar, S. (2013). Exploring the causal link between FDI and human capital development in India. Decision, 40, 3-13. https://doi.org/10.1007/s40622-013-0001-5

Kaufmann, D., Aart K. and Massimo M. (2009). Governance Matters VIII: Aggregate and Individual Governance Indicators for 1996-2008. World Bank Policy Research Working Paper No. 4978. Washington, D.C. https://doi.org/10.1596/1813-9450-4978

Kiyota, K., \& Urata, S. (2008). The Role of Multinational Firms in International Trade: The Case of Japan. Japan and the World Economy, 20(3), 338-352. https://doi.org/10.1016/j.japwor.2007.03.003

Kuzmina, O., Volchkova, N. and Zueva, T. (2014) Foreign Direct Investment and Governance Quality in Russia. Journal of Comparative Economics, 42(4), 874-891. https://doi.org/10.1016/j.jce.2014.08.001

Lu, Y., Tao, Z., \& Zhu, L. (2017). Identifying FDI spillovers. Journal of International Economics, 107, 75-90. https://doi.org/10.1016/j.jinteco.2017.01.006 
Makino, S., \& Delios, A. (1996). Local knowledge transfer and performance: Implications for alliance formation in Asia. Journal of International Business Studies, 27(5), 905-927. https://doi.org/10.1057/palgrave.jibs.8490156

Mengistu, A. A., \& Adhikary, B. K. (2011). Does good governance matter for FDI inflows? Evidence from Asian economies. Asia Pacific Business Review, 17(3), 281-299. https://doi.org/10.1080/13602381003755765

Mirzaie I. (2014). Government policy, inflation, and exchange rates in the era of sanctions: the case of contemporary Iran, Harvard economic review. Available from: http://harvardecon.org/?p=3106.

Moreira, S. B. (2009). The determinants of foreign direct investment: What is the evidence for Africa? Poiésis, Universidade do Sul de Santa Catarina, Santa Catarina, 2(1), 83-104. https://doi.org/10.19177/prppge.v2e3200983-104

Morisset, P. (2000). Foreign direct investment to Africa: Policies also matter. Trans-national corporation, 9(2), $107-125$.

Mowatt, R., \& Zulu, T. (1999). Intra-Regional Private Capital Flows in Eastern and Southern Africa: A study of South African investment in the Region. ACREFSA/FDI workshop on Intra-Regional Private Capital Flows in Eastern and Southern Africa, Harare.

Musibah, S., Shahzad, A., \& Fadzil, F. (2015). Impact of Foreign Investment in the Yemen's Economic Growth: The Country Political Stability as the Main Issue. Asian Social Science, 11(4), 102-116. https://doi.org/10.5539/ass.v11n4p102

Ndeffo, L.N. (2010). Foreign direct investments and human capital development in Sub-Saharan Africa. Economics and Applied Informatics, XVI (2), pp. 37-50.

Nonnemberg, M. B. and Cardoso de Mendona, M. J. (2004). the determinants of foreign direct investment in developing countries. Available from: http://www.anpec.org.br/encontro2004/artigos/A04A061.pdf

Nurudeen, A., Auta, E. M., \& Wafure, O. G. (2011). Determinants of Foreign Direct Investment in Nigeria: An Empirical Analysis. Global Journal of Human Social Science, 10(1), 26-34.

OECD (2004). The impact of trade-related intellectual property rights on trade and foreign direct investment in developing countries, working party of the Trade Committee, No. 42.

OECD (2016). Country Risk Report.

Parajuli, S., \& Kennedy, P. L. (2010). The Exchange Rate and Inward Foreign Direct Investment in Mexico, Paper Presented at the Southern Agricultural Association, Florida, USA.

Sahoo, P. (2006). Foreign direct investment in South Asia: Policy, trends, impact and determinants. Discussion Paper, No. 56, Asian Development Bank Institute, Tokyo.

Salim, A., Razavi, M. R., Afshari-Mofrad, M., Saleh, A. S., Anh Nguyen, T. L., Vinen, D., Zueva, T. (2017). The determinants of FDI and the impact of the economic crisis on the implementation of RTAs: A static and dynamic gravity model. International Business Review, 24(1), 0-1.

Samimi, A. J. \& Ariani F. (2010). Governance and FDI in MENA Region. Australian Journal of Basic and Applied Sciences, 4(10), 4880-4882.

Shahzad, A., \& Al-Swidi, A. K. (2013). Effect of macroeconomic variables on the FDI inflows: The moderating role of political stability: An evidence from Pakistan. Asian Social Science, 9(9), 270-279. https://doi.org/10.5539/ass.v9n9p270

Soltani, E., \& Wilkinson, A. (2011). The Razor's edge: Managing MNC affiliates in Iran. Journal of World Business, 46(4), 462-475. https://doi.org/10.1016/j.jwb.2010.10.007

Stack, M. M., Ravishankar, G., \& Pentecost, E. (2017). Foreign direct investment in eastern European countries: Determinants and performance. Structural Change and Economic Dynamics, 41, 86-97. https://doi.org/10.1016/j.strueco.2017.04.005

Tan, K. G., \& Tan, K. Y. (2015). Foreign direct investment and small and medium enterprises. Productivity and Access to Finance. World Scientific. https://doi.org/10.1142/9616

Tang, C. F., Yip, C. Y., \& Ozturk, I. (2014). The determinants of foreign direct investment in Malaysia: A case for electrical and electronic industry. Economic Modelling, 43, 287-292. https://doi.org/10.1016/j.econmod.2014.08.017

The Business Year (2013). Organization for Investment, Economic and Technical Assistance of Iran.

The Global Competitiveness Report (2014). World Economic Forum, Retrieved September 5.

UNCTAD (1999). World Investment Report, Geneva

UNCTAD (2000) World Investment Report, Geneva

UNCTAD (2009). The role of international investment agreements in attracting foreign direct investment to developing countries. UNCTAD Series on International Investment Policies for Development.

UNCTAD (2013). World Investment Report, Geneva

UNCTAD (2014). World Investment Report 2014: Investing in the SCGs- An action plan.

UNCTAD (2015). World Investment Report, Geneva

UNCTAD (2019). World Investment Report, Geneva

UNIDO (2010). United Nations Industrial Development Organization. An Overview of the Economy of the Islamic Republic of Iran. Retrieved September 24, 2010. 
Vedia-Jerez, D. H., \& Chasco, C. (2016). Long-run determinants of economic growth in South America. Journal of Applied Economics, 19(1), 169-192. https://doi.org/10.1016/S1514-0326(16)30007-1

Villaverde, J., \& Maza, A. (2015). The determinants of inward foreign direct investment: Evidence from the European regions. International Business Review, 24(2), 209-223. https://doi.org/10.1016/i.ibusrev.2014.07.008

World Economic Forum (2016). Global Competitiveness Report, Retrieved September 28, 2016.

World Investment Report (2008). United Nations Conference, Country fact sheet :1-2.

Yamin, M., \& Sinkovics, R. R. (2009). Infrastructure or foreign direct investment? An examination of the implications of MNE strategy for economic development. Journal of World Business, 44(2), 144-157. https://doi.org/10.1016/j.jwb.2008.05.004

Yao, S., \& Wei, K. (2007). Economic growth in the presence of FDI: The perspective of newly industrializing economies. Journal of Comparative Economics, 35(1), 211-234. https://doi.org/10.1016/j.jce.2006.10.007

Yoo, D., \& Reimann, F. (2015). Internationalization of Developing Country Firms into Developed Countries: The Role of Host Country Knowledge-Based Assets and IPR Protection in FDI Location Choice. Journal of International Management, November 2015, 0-1.

Zheng, J., \& Sheng, P. (2017). The Impact of Foreign Direct Investment (FDI) on the Environment: Market Perspectives and Evidence from China. Economies, 5(1), 8. https://doi.org/10.3390/economies5010008
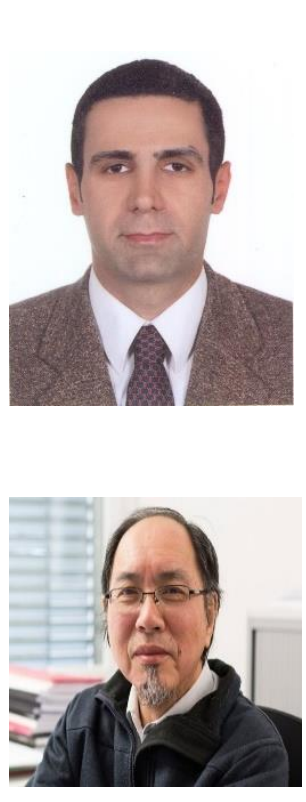

\section{AUTHORS' SHORT BIOGRAPHIES}

Dr. Mehdi Rasouli Ghahroudi is an Assistant Professor at the Institute for Management and Planning Studies (IMPS) in Tehran. He received his $\mathrm{PhD}$ in international business in 2009 from the University of Tsukuba, Japan. He was a Postdoctoral Researcher from 2013 to 2015 at the University of St. Gallen, Switzerland. Dr. Rasouli's research interests focus on international management, FDI, corporate governance, commercialization, and international marketing. He has published several papers in the above-mentioned research subjects. He has also work experience in a variety of industries as a Sales and Marketing Manager.

E-mail: m.rasouli@imps.ac.ir

ORCID iD: https://orcid.org/0000-0003-3322-0192

Professor Li Choy Chong has been teaching Transformational Leadership at the Zagreb School of Economics and Management since 2010. He also was the Chair for International Management, and Director of the Asia Research Centre at St. Gallen University in Switzerland, a Senior Advisor to the Office of the Economy at St. Gallen University. He is a Full Professor Emeritus of Management with a special focus on International Management, particularly in South East Asia. His research area includes international management, SMEs, internationalization, cross-border acquisition, and transition economies.

E-mail: $\underline{\text { i-choy.chong@unisg.ch }}$ 